\title{
PERBANDINGAN GLUKOSURI PADA REMAJA OBES DENGAN YANG TIDAK OBES
}

\author{
${ }^{1}$ Carrolina J.B. Lindo \\ 2Johnny Rompis \\ ${ }^{2}$ Vivekenanda Pateda
}

\author{
${ }^{1}$ Kandidat Skripsi Fakultas Kedokteran Universitas Sam Ratulangi Manado \\ ${ }^{2}$ Bagian Ilmu Kesehatan Anak Fakultas Kedokteran Universitas Sam Ratulangi Manado \\ Email: clindo11_154@ymail.com
}

\begin{abstract}
Glucosuria is the condition when glucose excreted into the urine. Supposedly urine does not contain glucose, because renal filtration will absorb glucose back into the blood circulation. One of the factors that could cause glucosuri is obesity. When plasma glucose level in obese adolescents still in normal range, it would not lead to the secretion of glucose in urine. Otherwise, if the plasma glucose levels are higher than normal, kidneys cannot be longer resist the renal threshold value for glucose (180 g/day) and there will be a partial excretion of glucose in urine.This study aimed to look the glucose urine level in children, obese and non-obese, at St. Rafael junior high school students Manado. This study was held on September to December 2014. This was a descriptive study with cross-sectional design. Samples were 100 teenagers that met the inclusion criteria who had nutritional status of obese and normal weight, and were willing to become respondents. The results showed that glucose in the urine of 100 samples wich divided into 50 samples of obese and 50 samples of nonobese were negative in both groups. Conclusion: There was no correlation between obesity and glucosuria in obese teenagers since their urine glucose levels did not reach the kidney treshold.
\end{abstract}

Keywords: glucosuria , obesity , normal weight.

\begin{abstract}
Abstrak: Glukosuria adalah ekskresi glukosa ke dalam urin. Seharusnya dalamurin tidak mengandung glukosa, karena ginjal akan menyerap glukosa hasil filtrasi kembali ke dalam sirkulasi darah. Salah satu faktor yang dapat menyebabkan glukosuri adalah obesitas. Padaremajadengan obesitas apabilakadar gula plasma masih dalam keadaan normal maka tidak akan menyebabkan terjadinya sekresi glukosa dalam urin. Sebaliknya, bila obesitas dengan kadar glukosa plasma lebih dari normal sehingga ginjal tidak bisa lagi menahan nilai ambang batas ginjal untuk glukosa (180 g/hari) maka akan terjadi eksresi sebagian glukosa melalui urin. Penelitian ini bertujuan untuk melihat adakah glukosa dalam urin pada anak remaja obes dan tidak obes pada siswa-siswi SLTP St.Rafael Manado. Penelitian ini dilakukan pada bulan September-Desember 2014. Jenis penelitian bersifat deskriptif dengan rancangan potong lintang. Sampel penelitian sebanyak 100 orang sesuai dengan kriteria inklusi yaitu remaja, memiliki status gizi obesitas dan berat badan normal, dan bersedia menjadi responden. Hasil pemeriksaan glukosa dalam urin pada 100 sampel yang terbagi dalam 50 sampel obes dan 50 sampel tidak obes adalah negatif. Simpulan: Tidak terdapat hubungan antara obesitas dengan glukosuria pada remaja obes yang belum mencapai ambang batas ginjal.
\end{abstract}

Kata kunci: glukosuri, obesitas, berat badan normal.

Federal Healthy People 2020 mengidentifikasi obesitas sebagai salah satu indikator kesehatan terkemuka pada anak-anak dan remaja yang mengalami obesitas. Prevalensi nasional obesitas dipantau menggunakan data dari National 
Health and Nutritiong Examination Survey (NHANES). Hasil dari 2009-2010 NHANES, menggunakan pengukuran tinggi dan berat badan, menunjukkan bahwa sekitar $16,9 \%$ dari anak-anak dan remaja berusia 2-19 tahun mengalami obesitas. Antara 1976-1980 dan 2009-2010, prevalensi obesitas meningkat. ${ }^{1}$ Dari hasil laporan beberapa tahun terakhir, obesitas di dunia meningkat tiga kali lipat. Lebih dari 1,2 miliar penduduk dunia termasuk berat badan berlebih dan sekitar 350 juta diantaranya dalam kategori obesitas. ${ }^{2}$

Obesitas juga sangat menonjol di negara-negara berkembang terutama di Indonesia, sekitar $18 \%$ populasi remaja dan lebih $35 \%$ populasi dewasa mempunyai berat badan berlebihan atau obesitas. Sejak tahun 1970 hingga sekarang, kejadian obesitas meningkat dua kali lipat pada anak usia 2-5 tahun dan usia 12-19 tahun, bahkan meningkat tiga kali lipat pada anak usia 6-11 tahun. Di Indonesia, prevalensiobesitas pada anak usia 6-15 tahun meningkat dari 5\% di tahun 1990 menjadi $16 \%$ di tahun $2001 .^{3}$

Prevalensi nasional anak dengan obesitas pada usia sekolah (6-14 tahun) gemuk lelaki adalah 9,5\% sedangkan gemuk perempuan adalah 6,4\%. Riset Kesehatan Dasar (Riskesdas) tahun 2010 dapat dilihat bahwa di Indonesia prevalensi obesitas berdasarkan IMT umur 6-12 tahun didapati pada anak lelaki sebesar $10,7 \%$ dan pada anak perempuan sebesar 7,7\%. Kejadian obesitas pada anak di Provinsi Sulawesi Utara sebesar 6,4\%. Di masa mendatang, persoalan gizi lebih pada anak diprediksi akan lebih meningkat dibandingkan kasus gizi kurang, sedangkan prevalensi obesitas pada anak SD di Manado berkisar 21\%-25\%. ${ }^{4}$

Pola makan yang tidak sehat dan berlebihan secara kualitas maupun kuantitas seperti banyak dan sering makan makanan siap saji, makanan yang manis dan mempunyai nilai nutrisi rendah, serta makanan yang tinggi gula terutama gula sederhana, lemak dan garam memiliki pengaruh yang besar untuk terjadinya obsitas. $^{5}$ Tingginya asam lemak, peningkatan hormon resistin dan penurunan adiponektin akibat penumpukan lemak pada penderita obesitas memengaruhi kerja insulin sehingga dapat menyebabkan tingginya kadar glukosa darah. ${ }^{6}$

Jika glukosa darah meningkat hingga kadar yang relatif tinggi, ginjal juga akan melaksanakan efek-efek regulatorik. Glukosa secara terus-menerus difiltrasi oleh glomerulus, tetapi dalam keadaan normal direabsorbsi secara sempurna di tubulus ginjal melalui transport aktif. Kapasitas sistem tubulus untuk menyerap glukosa terbatas hingga kecepatan sekitar $350 \mathrm{mg} / \mathrm{menit}$, dan pada hiperglikemia seperti dijumpai pada diabetes melitus yang tidak terkontrol, filtrasi glomerulus dapat mengandung lebih banyak glukosa dari pada yang dapat direabsorbsi sehingga terjadi glukosuria. Glukosuria terjadi jika konsentrasi glukosa serum melebihi ambang reabsorbsi ginjal (biasanya sekitar $180 \mathrm{mg} / \mathrm{dL}){ }^{2,7}$

\section{METODE PENELITIAN}

Penelitian ini bersifat deskriptif dengan rancangan potong lintang dan di lakukan pada bulan September sampai Desember 2014. Populasi dan sampel ialah siswasiswi SLTP St.Rafael Manado, yang memenuhi kriteria inklusi antara lain: remaja, berat badan obes dan normal, sehat saat diperiksa, bersedia menjadi responden dan tidak mempunyai kelainan fisik bawaan dan riwayat gangguan metabolik.

Alat-alat yang digunakan yaitu tabung, strip test urinalisis, timbangan, microtoise dan kurva CDCBMI-for-age growth chart yang dibedakan berdasarkan jenis kelamin. Bahan yang digunakan adalah urin sewaktu.

\section{HASIL PENELITIAN}

Penelitian ini dilaksanakan di SMP St.Rafael Manado. Pemilihan sampel dilakukan secara acak dari siswa-siswi kelas 1 sampai kelas 3 yang diharapkan masuk dalam kategori obes dan tidak obes. Penelitian ini diikuti oleh 100 siswa yang terbagi dalam 50 siswa obes dan 50 siswa yang tidak obes. 
Tabel 1. Distribusi sampel berdasarkan kelompok umur

\begin{tabular}{|c|c|c|c|c|}
\hline \multirow{2}{*}{$\begin{array}{l}\text { Umur } \\
\text { (tahun) }\end{array}$} & \multicolumn{2}{|c|}{ Obes } & \multicolumn{2}{|c|}{ Tidak obes } \\
\hline & $\mathbf{n}$ & $\%$ & n & $\%$ \\
\hline 11 & 6 & 12 & 9 & 18 \\
\hline 12 & 16 & 32 & 7 & 14 \\
\hline 13 & 11 & 22 & 16 & 32 \\
\hline 14 & 14 & 28 & 18 & 36 \\
\hline 15 & 3 & 6 & 0 & 0 \\
\hline Total & & & & \\
\hline
\end{tabular}

Berdasarkan distribusi Tabel 1, diketahui pada sampel dengan kategori obesitas yang berusia 12 tahun terdapat 16 responden dengan persentase 32\%, usia 14 tahun terdapat 14 responden dengan persentase $28 \%$, usia 13 tahun terdapat 11 responden dengan persentase $22 \%$, usia 11 tahun terdapat 6 responden dengan persentase $12 \%$ yang dan usia 15 tahun terdapat 3 responden dengan persentase 6\%. Sedangkan pada sampel dengan kategori tidak obes yang berusia 14 tahun terdapat 18 responden dengan persentase $36 \%$, usia 13 tahun terdapat 16 responden dengan persentase $32 \%$, usia 11 tahun terdapat 9 responden dengan persentase $18 \%$, usia 12 tahun terdapat 7 responden dengan persentase $14 \%$.
Berdasarkan distribusi Tabel 2, sampel berjenis kelamin lelaki terdapat 27 responden dengan persentase $43,5 \%$ yang memiliki berat badan normal, sedangkan lelaki yang memiliki berat badan obes terdapat 35 responden dengan persentase 56,5\%. Sampel berjenis kelamin perempuan terdapat 23 responden dengan persentase $60,5 \%$ yang memiliki berat badan normal, sedangkan perempuan yang memiliki berat badan obes terapat 15 responden dengan persentase 39,5\%.

Berdasarkan Tabel 3, terdapat 74 responden (74\%) yang sudah mengalami tanda-tanda pubertas, sedangkan yang belum pubertas terdapat 26 responden (26\%).

Tabel 2. Distribusi sampel berdasarkan klasifikasi obes dan tidak obes menurut jenis kelamin

\begin{tabular}{ccccccc}
\hline Klasifikasi & \multicolumn{2}{c}{ Lelaki } & \multicolumn{2}{c}{ Perempuan } & \multicolumn{2}{c}{ Total } \\
\cline { 2 - 7 } & $\mathbf{n}$ & $\mathbf{\%}$ & $\mathbf{n}$ & $\mathbf{\%}$ & $\mathbf{n}$ & $\mathbf{\%}$ \\
\hline Tidak obes & 27 & 43.5 & 23 & 60.5 & $\mathbf{5 0}$ & $\mathbf{5 0}$ \\
Obes & 35 & 56.5 & 15 & 39.5 & $\mathbf{5 0}$ & $\mathbf{5 0}$ \\
Total & $\mathbf{6 2}$ & $\mathbf{1 0 0}$ & $\mathbf{3 8}$ & $\mathbf{1 0 0}$ & $\mathbf{1 0 0}$ & $\mathbf{1 0 0}$ \\
\hline
\end{tabular}

Tabel 3. Distribusi sampel berdasarkan tanda-tanda pubertas pada remaja

\begin{tabular}{ccccccc}
\hline \multirow{2}{*}{ Kategori } & \multicolumn{2}{c}{ Obes } & \multicolumn{2}{c}{ Tidak obes } & \multicolumn{2}{c}{ Total } \\
\cline { 2 - 7 } & $\mathbf{n}$ & $\mathbf{\%}$ & $\mathbf{n}$ & $\mathbf{\%}$ & $\mathbf{n}$ & $\mathbf{\%}$ \\
\hline Tanda pubertas & 32 & 64 & 42 & 84 & 74 & 74 \\
Belum pubertas & 18 & 36 & 8 & 16 & 26 & 26 \\
Total & $\mathbf{5 0}$ & $\mathbf{1 0 0}$ & $\mathbf{5 0}$ & $\mathbf{1 0 0}$ & $\mathbf{1 0 0}$ & $\mathbf{1 0 0}$ \\
\hline
\end{tabular}


Tabel 4. Distribusi sampel obes berdasarkan jumlah makan dalam sehari

\begin{tabular}{ccc}
\hline $\begin{array}{c}\text { Jumlah } \\
\text { makanan / hari }\end{array}$ & $\mathbf{n}$ & $\mathbf{\%}$ \\
\hline $\mathbf{2}$ & 6 & 12 \\
$\mathbf{3}$ & 36 & 72 \\
$\mathbf{4}$ & 7 & 14 \\
$\mathbf{5}$ & 1 & 2 \\
Total & $\mathbf{5 0}$ & $\mathbf{1 0 0}$ \\
\hline
\end{tabular}

Berdasarkan distribusi pada Tabel 4, banyak sampel mengkonsumsi makanan sehari dalam jumlah yang normal dari 50 sampel kategori obes. Hanya 8 responden mengkonsumsi makanan dalam sehari dengan jumlah yang berlebihan. Tetapi jumlah makanan yang dimakan dalam sehari belum bisa membuktikan orang yang makan tiga kali sehari bertubuh kurus atau gemuk tanpa di tinjau dari porsi yang di makan setiap harinya.

Tabel 5. Distribusi sampel obes berdasarkan jumlah porsi yang dimakan dalam setiap kali makan

\begin{tabular}{ccc}
\hline $\begin{array}{c}\text { Jumlah porsi makan pada } \\
\text { setiap kali makan }\end{array}$ & $\mathbf{n}$ & $\mathbf{\%}$ \\
\hline $1 / 2$ & 1 & 2 \\
$\mathbf{1}$ & 27 & 54 \\
$\mathbf{1} 1 / 2$ & 8 & 16 \\
$\mathbf{2}$ & 12 & 24 \\
$\mathbf{3}$ & 2 & 4 \\
Total & $\mathbf{5 0}$ & $\mathbf{1 0 0}$
\end{tabular}

Berdasarkan distribusi pada Tabel 5, dapat dilihat sebanyak 27 sampel dengan persentase $54 \%$ mengkonsumsi 1 porsi makan dalam setiap kali makan dari 50 sampel kategori obesitas. 12 sampel dengan persentasi $24 \%$ pada urutan kedua terbanyak mengkonsumsi 2 porsi makan dalam setiap kali makan. Terdapat 8 sampel dengan persentase $16 \%$ mengkonsumsi $1 \frac{1}{2}$ porsi makan dalam setiap kali makan. Terdapat 2 sampel dengan persentase 4\% mengkonsumsi 3 porsi makan dalam setiap kali makan.Terdapat 1 sampel dengan persentase $2 \%$ mengkonsumsi $1 / 2$ porsi makan dalam setiap kali makan.

Tabel 6. Distibusi sampel obes berdasarkan kebiasaan ngemil

\begin{tabular}{ccc}
\hline $\begin{array}{c}\text { Kebiasaan } \\
\text { ngemil }\end{array}$ & n & $\mathbf{\%}$ \\
\hline Ya & 39 & 78 \\
Tidak & 11 & 22 \\
Total & $\mathbf{5 0}$ & $\mathbf{1 0 0}$ \\
\hline
\end{tabular}

Berdasarkan distribusi pada Tabel 6, dapat dilihat ada 29 sampel dengan persentase $78 \%$ memiliki kebiasaan ngemil dari 50 sampel kategori obesitas. Hanya terdapat 11 sampel dengan persentase 22\% tidak memiliki kebiasaan memakan cemilan. Umumnya sampel yang didapat sering mengemil dengan jumlah cemilan yang berlebihan dalam 1 minggu.

Berdasarkan distribusi pada Tabel 7, terdapat 22 sampel dengan persentase $44 \%$ tidak berolahraga dari 50 sampel dalam kategori obesitas. 16 sampel dengan persentasi $32 \%$ berolahraga selama $<30$ menit. 8 sampel dengan persentase 16\% berolahraga selama 1 jam. 2 sampel dengan persentase $4 \%$ berolahraga selama 2 jam. 2 sampel dengan persentase $4 \%$ berolahraga selama $>2$ jam. Pendataan kebiasaan berolahraga diluar jadwal olahraga sekolah.

Berdasarkan distribusi pada Tabel 8, dapat dilihat bahwa sampel yang memiliki anggota keluarga dengan obesitas sebanyak 42 orang dengan persentase $84 \%$ dari 50 sampel kategori obesitas. Hanya 8 orang dengan persentase $16 \%$ saja yang tidak memiliki anggota keluarga dengan obesitas. 
Tabel 7. Distribusi sampel obes berdasarkan kebiasaan dan kegiatan berolahraga dalam seminggu

\begin{tabular}{ccc}
\hline Lama berolahraga & $\mathbf{n}$ & $\mathbf{\%}$ \\
& & \\
\hline Tidak berolahraga & 22 & 44 \\
<30 Menit & 16 & 32 \\
1 Jam & 8 & 16 \\
2 Jam & 2 & 4 \\
> $\mathbf{~ J a m ~}$ & 2 & 4 \\
Total & $\mathbf{5 0}$ & $\mathbf{1 0 0}$ \\
\hline
\end{tabular}

\begin{tabular}{ccc}
\hline $\begin{array}{c}\text { Kegiatan } \\
\text { olahraga dalam } \\
\text { seminggu }\end{array}$ & n & \% \\
\hline $\begin{array}{c}\text { Tidak } \\
\text { berolahraga }\end{array}$ & 22 & 44 \\
1 Kali & 16 & 32 \\
2 Kali & 7 & 14 \\
3 Kali & 3 & 6 \\
$>$ 3 Kali & 2 & 4 \\
Total & $\mathbf{5 0}$ & $\mathbf{1 0 0}$ \\
\hline
\end{tabular}

Tabel 8. Distribusi sampel obes berdasarkan anggota keluarga yang mengalami obesitas

\begin{tabular}{ccc}
\hline $\begin{array}{c}\text { Anggota } \\
\text { keluarga yang } \\
\text { mengalami } \\
\text { obesitas }\end{array}$ & $\mathbf{n}$ & $\mathbf{\%}$ \\
\hline Ada & 42 & 84 \\
Tidak & 8 & 16 \\
Total & $\mathbf{5 0}$ & $\mathbf{1 0 0}$ \\
\hline
\end{tabular}

Tabel 9. Distribusi sampel obes berdasarkan komplikasi dari keluarga yang obesitas

\begin{tabular}{ccc}
\hline $\begin{array}{c}\text { Jumlah faktor risiko } \\
\text { kolesterol }\end{array}$ & $\mathbf{n}$ & $\mathbf{\%}$ \\
\hline Diabetes melitus & 9 & 25,75 \\
Penyakit ginjal & 3 & 43,6 \\
Asam urat & 22 & 33,3 \\
Hipertensi & 15 & 22,75 \\
Total & $\mathbf{6 6}$ & $\mathbf{1 0 0}$ \\
\hline
\end{tabular}

Berdasarkan distribusi pada Tabel 9, dapat dilihat bahwa faktor risiko penyakit yang terbanyak adalah asam urat dengan persentase $25,75 \%$ dari 50 sampel kategori obesitas, kolesterol dengan persentase $13,6 \%$, hipertensi dengan persentase 22,75\%, diabetes melitus dengan persentase $13,6 \%$ dan penyakit ginjal

dengan persentase $4,6 \%$.

Distribusi pada Tabel 10 menunjukan hasil pemeriksaan carik celup urinalisis glukosa. Dari 100 sampel yang terbagi dalam 2 kategori obes dan tidak obes memiliki hasil yang sama yaitu tidak terdapat glukosa dalam urin.

Tabel 10. Distribusi sampel obes dan tidak obes berdasarkan hasil pemeriksaan glukosuri

\begin{tabular}{cccc}
\hline Klasifikasi & $\mathbf{n}$ & Hasil & $\mathbf{\%}$ \\
\hline Tidak obes & 50 & Negatif & $\mathbf{5 0}$ \\
Obes & 50 & Negatif & $\mathbf{5 0}$ \\
Total & $\mathbf{1 0 0}$ & & $\mathbf{1 0 0}$ \\
\hline
\end{tabular}




\section{BAHASAN}

Pada Tabel 1 sampel obesitas terbanyak pada usia 12 tahun. Anak usia 11 tahun dengan gizi lebih berisiko dua kali lebih besar untuk tetap berstatus gizi lebih pada usia 15 tahun di bandingkan anak usia 7 tahun dengan gizi lebih. ${ }^{2}$ Hasil penelitian ini diperkuat juga dari data Riskesdas yang menunjukkan prevelensi gizi lebih di Indonesia pada kelompok anak usia 6-12 tahun sebesar 9,2\%, kelompok usia 13-15 tahun sebesar 2,5\% dan kelompok anak usia $16-18$ tahu sebesar $1,4 \% .^{8}$

Tabel 2 menunjukkan sampel berjenis kelamin lelaki dengan obesitas lebih banyak jumlahnya dibandingkan dengan perempuan. Hasil penelitian ini sesuai dengan penelitian yang dilakukan oleh Ratu Sartika bahwa anak lelaki memiliki risiko mengalami obesitas sebesar 1,4 kali dibandingkan anak perempuan. ${ }^{9}$

Tabel 3 telah menunjukkan lebih dari $70 \%$ responden mengalami tanda-tanda pubertas. Hal ini sesuai dengan teori yang menyatakan bahwa pubertas awal pada remaja perempuan dan lelaki terjadi pada usia 8-16 tahun. ${ }^{2}$

Dari hasil penelitian juga di dapatkan bahwa besar sampel kategori tidak obes lebih banyak telah menunjukkan tandatanda pubertas dari pada yang sampel yang obes. Hal ini bisa di lihat dari hasil pengamatan berdasarkan kelompok umur. Pada Tabel.1 sampel dengan kategori tidak obes lebih banyak telah berusia 13-14 tahun dan sampel dengan kategori obes lebih banyak telah berusia 11 tahun. Inilah yang mengakibatkan jumlah sampel yang tidak obes sudah mendapatkan tanda-tanda pubertas lebih banyak dari pada sampel yang obes.

Hasil penelitian juga menunjukkan responden yang tidak obes lebih banyak mengalami tanda-tanda obesitas dibandingkan yang obes. Dari beberapa teori mengatakan obesitas pada masa anakanak dan remaja berkaitan dengan sejumlah manifestasi klinis, salah satunya maturasi dini. $^{10}$ Diketahui bahwa pertumbuhan pubertas awal remaja perempuan biasanya timbul pada rentang usia 8-13 tahun, yang ditandai dengan perubahan pada breast budding dan pertumbuhan rambut pubis yang lurus dan halus diatas mons pubis yang biasanya timbul pada usia 11 tahun. Sedangkan pada remaja lelaki timbul pada usia 10,5 sampai 16 tahun, yang diawali dengan terjadi pembesaran testis diikuti dengan tumbuhnya rambut pubis. ${ }^{2}$

Tabel 4 dan 5 menunjukkan sebagian besar responden mengkonsumsi makanan dalam jumlah yang normal yaitu makan makanan tiga kali dalam sehari. Dari hasil pengamatan porsi makan dalam setiap kali makan lebih dari satu porsi pada setiap kali makan. Normalnya, dalam setiap kali makan ukuran kebutuhan karbohidrat seperti nasi adalah 100 gram atau sama dengan $3 / 4$ gelas dalam ukuran rumah tangga, ukuran kebutuhan protein hewani seperti daging sapi adalah 50 gram atau 1 potong dan untuk sayuran campur adalah 100 gram atau 1 gelas dalam ukuran rumah tangga. ${ }^{11}$ Dari anamnesis beberapa sampel didapatkan pada setiap kali makan, porsi yang di makan lebih dari 100 gram untuk nasi, lebih dari 50 gram untuk daging dan lebih dari 100 gram untuk sayuran. Kebiasaan makan tersebut jelas dapat memicu meningkatnya berat badan anak tersebut.

Hasil penelitian ini sesuai dengan penelitian yang di lakukan oleh Andrianus Mujur tentang "hubungan antara pola makan dan aktivitas fisik dengan kejadian berat badan lebih pada remaja" yang menyatakan pola makan merupakan faktor risiko dari kejadian obesitas, dimana anak yang mempunyai pola makan berlebih sangat berisiko untuk mempunyai berat badan lebih dan secara statistik terdapat hubungan bermakna antara pola makan dan berat badan lebih. ${ }^{12}$

Tabel 6 menunjukkan lebih dari 70\% sampel dengan obesitas memiliki kebiasaan ngemil. Dalam hal ini cemilan yang sering di makan yaitu makanan ringan, makanan cepat saji, minuman bersoda dan es krim. Makanan-makanan tersebut cenderung mengandung lemak, protein, hidrat arang dan garam yang relatif tinggi dan dengan kemungkinan konsekuensi seperti 
kegemukkan, tekanan darah tinggi, diabetes mellitus dan lainnya. ${ }^{13}$ Hasil penelitian ini sesuai dengan penelitian yang di lakukan oleh Oktavianus bahwa adanya hubungan yang signifikan antara kebiasaan konsumsi makanan cepat saji dengan berat badan. Semakin sering mengkonsumsi makanan cepat saji, maka semakin besar nilai IMT dan begitu juga sebaliknya. ${ }^{14}$

Tabel 7 menunjukkan sebagian besar sampel malas berolahraga, serta lama berolahraga para responden $<1$ jam tapi tidak di lakukan secara benar. Dari anamnesis beberapa sampel, pada umumnya olahraga yang di lakukan adalah senam pagi atau jalan pagi. Kegiatan olahraga pun tidak di lakukan secara rutin setiap minggunya. Hal ini menyebabkan energi yang mereka keluarkan tidak sesuai dengan asupan makanan sehingga mengakibatkan kelebihan energi dakam tubuh. Normalnya, olahraga yang dianjurkan dilakukan 30 menit -1 jam 3-5 kali seminggu. ${ }^{15}$ Hasil penelitian ini sesuai dengan penelitian yang dilakukan oleh Andriadus Mujur dimana pola makan yang tergolong baik sedangkan aktivitas fisiknya tergolong aktivitas fisik ringan, sehingga energi yang dikeluarkan tidak sesuai dengan asupan pangan, hal ini bila berlangsungdalam kurun waktu yang lama dapat berakibat terjadi penumpukkan lemak di bawah kulit yang akhirnya terjadi berat badan lebih bahkan bisa terjadi obesitas. ${ }^{12}$

Tabel 8 menujukkan $84 \%$ sampel dengan obesitas mempunyai keluarga dengan riwayat yang sama. Obesitas yang terjadi dalam keluarga dihubungkan dengan faktor genetik atau pengaruh pajanan lingkungan yang sama. Jadi, pengaruh hereditas membuat seseorang rentan terhadap obesitas, namun pengaruh lingkungan dan perilaku menentukan cara genetik yang rentan tersebut dinyatakan., ${ }^{2,10}$ Hasil penelitian ini di dukung dengan hasil penelitian oleh Budiyati $\mathrm{dkk}^{16}$ tentang "hubungan indeks massa tubuh ayah dan ibu dengan kejadian obesitas pada anak usia sekolah" yang mempunyai hasil bahwa terdapat hubungan bermakna anatara IMT Ayah dengan kejadian obesitas pada anak dan terdapat hubungan bermakna anatara IMT ibu dengan kejadian obesitas pada anak.

Pada tabel 9 terdapat beberapa penyakit yang berhubungan dengan obesitas. Hasil penelitian menunjukkan sampel dengan kategori obesitas yang memiliki keluarga yang obes juga telah menderita komplikasi akibat berat badan yang berlebihan. Hal ini tentu dapat terjadi bagi para responden bila tidak mengontrol kesehatan dan menjaga berat badan agar tetap ideal sejak dini.

Hasil penelitian ini sesuai dengan penelitian yang di lakukan oleh Listyana $\mathrm{dkk}^{17}$ adanya hubungan antara obesitas dengan meningkatnya kadar kolesterol dari pola makan yang berlebihan dan tidak diimbangi dengan olahraga yang teratur. Penelitian ini juga sesuai dengan penelitian yang dilakukan oleh Lumuindong $\mathrm{dkk}^{18}$ tentang "hubungan obesitas dengan profil tekanan darah pada anak usia 10-12 tahun di kota Manado" bahwa terdapat hubungan antara obesitas dan profil tekanan darah pada anak.

Hasil penelitian ini sesuai dengan peneliti yang di lakukan oleh Farida Soetiarto dkk bahwa obesitas lebih berperan sebagai faktor risiko terjadinya DM 2,26 kali lebih berperan dari yang tidak obes. ${ }^{19}$ Hasil penelitian ini sesuai dengan penelitian yang dilakukan oleh Yohan $\mathrm{dkk}^{20}$ adanya hubungan yang kuat anatar indeks massa tubuh dengan laju filtrasi glomerulus. Hasil penelitian ini sesuai dengan penelitian yang di lakukan oleh Zahara yang menyatakan adanya hubungan antara gout dan faktor makanan dengan kandungan purin yang tinggi. ${ }^{21}$

Pada Tabel 10 hasil pemeriksaan glukosa dalam urin pada sampel dengan obes dan tidak obes adalah negatif. Glukosa secara terus menerus difiltrasi oleh glomerulus, tetapi dalam keadaan normal direabsorbsi secara sempuran di tubulus ginjal melalui transport aktif. Glikosuria terjadi jika konsentrasi glukosa plasma melebihi ambang reabsorbsi ginjal (biasanya sekitar $180 \mathrm{mg} / \mathrm{dL}$ ). Dari hasil penelitian dapat dilihat bahwa kadar 
glukosa sampel belum mencapai ambang ginjal untuk glukosa walaupun status gizi anak dalam kategori obesitas, sehingga hasil pemeriksaan glukosa dalam urin adalah negatif. $^{7}$

\section{SIMPULAN}

Berdasarkan hasil pemeriksaan glukosa urin pada remaja obes dan tidak obes di SLTP St.Rafael Manado, didapatkan bahwa tidak ada hubungan antara obesitas dengan glukosuria pada remaja obes yang belum mencapai ambang batas ginjal.

\section{SARAN}

Dibutuhkan suatu penelitian yang lebih lanjut dimana melibatkan jumlah sampel yang lebih besar dan jangkauan umur yang lebih luas untuk lebih memahami hubungan antara glukosa dalam urin pada anak obes.

Pada anak obes bila tidak ditangani lebih lanjut maka akan meneyebabkan terjadinya gangguan metabolik. Untuk itu diperlukan mengubah pola hidup yang benar dengan meningkatkan ativitas fisik dan makan makanan yang bergizi.

\section{DAFTAR PUSTAKA}

1. Cheryl D, Margaret D, Cynthia L. Prevalence of obesity among children and adolescents: United States, Trends 1963-1965 Through 20092010. National center of health statistic. September 2012.[7 Januari 2015]. Diunduh dari: http://www.cdc.gov/nchs/data/hestat/ obesity_child_09_10/obesity_child_0 9_10.pdf .

2. Levine.D.A. Pertumbuhan dan perkembangan. Dalam: Marcdante K.J, Kliegman R.M, Jenson H.B, Berhman R.E. Nelson Ilmu Kesehatan Anak. vol 1. Edisi keenam. Singapur : Elsevier;2011. hal 122-3, 296-9.

3. Sartika R, D. Faktor risiko obesitas pada anak 5-15 Tahun di Indonesia.Falkutas Kesehatan Masyarakat Universitas Indonesia2011 . [ 18 September 2015]. Diunduh dari: http://journal.ui.ac.id/health/article/do wnload/796/758
4. Parengkuan R.R, Malluyu N, Ponidjan T. Hubungan pendapatan keluarga dengan kejadian obesitas pada anak sekolah dasar di kota Manado.Jurnal Keperawatan. 2013. [28 september 2014]. Diunduh dari: http://ejournal.unsrat.ac.id/index.php/ jkp/article/view/2227

5. Batubara J.R.L, Tridjaja B, Pulungan A.B. Buku ajar endokrinologi anak. Edisi pertama. Jakarta: Baan Penerbit IDAI. 2010. hal 355.

6. Lipoeto N. I, Mc, Yerizel E, Edward Z,MS, Widuri I. Hubungan nilai antropometri dengan kadar glukosa darah. Falkutas Kedokteran Universitas Andalas. 2007. [ 19 September 2014]. Diunduh dari: http://repository.unand.ac.id/49/1/gul a_darah_dan_antro.pdf .

7. Murray R. K, Granner D. K, Rowell V. W. Biokimia Harper. Edisi 27.Jakarta: Buku Kedoteran EGC; 2009. hal 182.

8. Rafiony A. Konsumsi fast food dan soft drink sebagai faktor risiko obesitas pada remaja Sekolah Menengah Atas (SMA) di Kota Pontianak. Universitas Gajah Mada. 2013. [ 2 Januari 2015]. Diunduh dari : http://etd.ugm.ac.id/index.php?mod= penelitian_detail\&sub=PenelitianDeta il\&act=view\&typ=html\&buku_id=66 897\&is_local $=1$.

9. Sartika R.A.D. Faktor risiko obesitas pada anak 5-15 tahun di Indonesia. Falkutas Kesehatan Masyarakat Universitas Indonesia.2011.[12 Januari 2015]. Diunduh dari: http://journal.ui.ac.id/health/article/do wnload/796/758

10. Thomas N, Robinson, Dietz W.H. Berat Badan Bertambah: Makan berlebihan hingga obesitas. Dalam : Rudolph A, Hoffman J, Rudolph C. Buku Ajar Pediatri Rudolph. Volume 1. Edisi 20.Jakarta: EGC,2014. hal 179-80

11. Almatsier S. Prinsip Dasar Ilmu Gizi. PT Gramedia Pustaka Utama. Cetakan kedelapan. Jakarta:2009.hal 297

12. Mujur A. Hubungan antara pola makan dan aktivitas fisik dengan kejadian berat badan lebih pada remaja. Falkutas Kedokteran Unvesitas Diponegoro.2011. [3 Januari 2015]. 
Diunduh

dari:

http://eprints.undip.ac.id/32809/

13. Intan N.R. Faktor-faktor yang berhubungan dengan obesitas berdasarkan persen lemak tubuh pada remaja di SMA Islam Terpadu Nurul Fikri Depok. Falkutas Kesehatan Masyarakat Universitas Indonesia. 2008. [ 3 Januari 2015]. Diunduh dari:

http://lib.ui.ac.id/file?file=digital/123 610-S-5435-Faktor\%20faktor-

Analisis.pdf

14. Oktaviani W.D, Saraswati L.D, Rahfiludin M.Z. Hubungan kebiasaan konsumsi fast food, aktivitas fisik, pola konsumsi, karakteristik remaja dan orang tua dengan Indeks Massa Tubuh (IMT). Jurnal Kesehatan Masyarakat. 2012. [ 12 Januari 2015]. Diunduh dari : http://ejournals1.undip.ac.id/index.ph $\mathrm{p} / \mathrm{jkm}$

15. Irfan M. Pedoman berolahraga yang menyehatkan. Program Studi Kesehatan dan Rekreasi Universitas Negri Medan. Volume.2011.[11 Januari 2015]. Diunduh dari: http://digilib.unimed.ac.id/public/UNI MED-Journal-22198Jurnal\%20Irfan\%20PJKR-FIK.pdf

16. Budiyati, Wanda $D$, Haryoto $M$. Hubungan indeks massa tubuh ayah dan ibu dangen kejadian obesitas pada anak usia sekolah di SD Islam Al-Azhar 14 Kota Semarang. Jurnal Keperawatan Anak. 2013. [ 3 Januari 2015]. Diunduh dari : http://jurnal.unimus.ac.id/index.php/J KA/article/view/906/960

17. Listyana A, mardiana, Prameswari G. Obesitas sentral dan kadar kolesterol darah total. Jurnal Kesehatan Masyarakat. 2013. [ 3 Januari 2015]. Diunduh dari: http://journal.unnes.ac.id/nju/index.ph $\mathrm{p} /$ kemas.

18.Lumuindong A, Umboh A, Masloman N. Hubungan obesitas dengan profil tekanan darah pada anak usia 10-12 tahun di kota Manado. Jurnal ebiomedik. 2013. [ 3 Januari 2015]. Diunduh dari: http://download.portalgaruda.org/artic le.php?article $=107955 \& v a l=1008$.

19. Soetiarto F, Roselinda, Suhardi. Hubungan diabetes mellitus dengan obesitas bersdasarkan indeks massa tubuh dan lingkar pinggang data Riskesdas 2007. Buletin penelitian kesehatan 2010. [ 3 Januari 2015] di unduh dari: http://ejournal.litbang.depkes.go.id/in dex.php/BPK/article/view/121/185 .

20. Yohan H.O.P, Waleleng B.J, Wantania F. Hubungan antara indeks massa tubuh dengan estimasi laju filtrasi glomerulus pada mahasiswa dengan obesitas di Falkutas Kedokteran Universitas Sam Ratulangi Manado. November 2013. [3 Januari 2015]. Diunduh dari: ejournal.unsrat.ac.id/index.php/eclini c/article/download/3659/3185

21. Zahara R. Artitis gout metakarpal dengan perilaku makan tinggi purin diperberat oleh aktivitas mekanik pada kepala keluarga dengan posisi menggenggam statis. Medula. 2013. [4 Januari 2015]. Diunduh dari: http://juke.kedokteran.unila.ac.id/inde x.php/medula/article/view/115. 